\title{
Defying Secular Trend
}

\author{
Nassar MF* \\ Faculty of Medicine, Ain Shams University, Egypt
}

Submission: July 31, 2017; Published: August 09, 2017

*Corresponding author: Nassar MF, Faculty of Medicine, Ain Shams University, Egypt, Email: maynassar@med.asu.edu.eg

\section{Short Communication}

The secular variation of biological anthropology was proposed to assess the degree of socio-economic development of a country or region, providing important information for public health policies orientation [1]. This gives us an insight regarding how hard nations try to achieve better secular trends of growth. Samaras [2] emphasized that with healthful nutrition and lifestyles and good medical care, shorter people are less likely to suffer from age-related chronic diseases and more likely to reach advanced ages. Nevertheless, taller height has been often described as a sign of social status and privilege [3], therefore it became a personal as well as a society wish. Generally, in the last decades, stature tends to stabilize; however, weight continues to grow causing overweight to take pandemic forms in developed countries [4]. Given that nutrition and genetics are the main determinants of height trends and since maximum genetic potential can be restrained by many environmental factors [5]; nutrition became a sole player.

Over-enthusiasm in diet manipulation aiming to achieve a positive height trend can come at a high cost regarding weight. During the pursue for the best measures and taking much proteins and calories aiming at a taller posture with perhaps some extra muscle mass; one can risk later health hazards. Singhal et al. [6] reported that growth acceleration correlates with longterm health problems in humans and animals. Additionally, a systematic review by Monteiro \& Victora [7] concluded that most studies show a positive association between rapid growth (height, weight, or both) and increased overweight and obesity, regardless of age. The latter authors further warned us from the cardiac sequel of rapid catch-up growth. Therefore, the ultimate goal is to defy the secular trend and achieve a better height potential without the health burdens of excess weight. In Europe, it was found that protein quality rather than quantity is what truly makes a difference in height. Although nutrition in most countries can be raised by rational dietary guidelines irrespective of the economic indicators, the deterioration of the protein index (ratio between proteins of highest quality as those of animal origin to the plant protein mainly wheat), even in the wealthiest nations, is alarming [5]. Thus the myth is giving up on height and believing in the exhaustion of the genetic potential theory. The truth, on the other hand, is that there is still hope lying in our right choice of protein. Don`t forget that the tallest people in Europe before the start of the industrial revolution may have been the hunters from the Gravettian culture with their high quality animal protein diet [8]. Although in non-European countries the main correlate of height is not protein quality but total protein consumption, with the increasing consumption of total protein Grasgruber et al. [9] found large differences in height at the same consumption level, which takes us back to the importance of protein quality. Current threats to protein quality can explain the observed negative height trends. These threats can result from a combination of the inadequate "fast-food" nutrition and some new and rather fashionable dietary guidelines such as "modern healthy eating plates" [10]. Surprisingly enough these dietary guidelines are currently popular despite the fact that there is limited milk intake and emphasis on vegetables and whole grains at the expense of animal proteins which can lead to poor outcome at least in the pediatric age group [5].

Besides the decreased protein quality and its contribution to the decreased height potential, fast food is actually a double burden since the obesity hazard is a direct consequence [11]. Unhealthy energy-dense, high-fat, low-fiber density dietary pattern was associated with a significantly higher risk of obesity as recently described by Jessri et al. [12]. In simple words fighting the fast food epidemic, can help achieve a better secular trend whether taller height or desired weight. Finally, adherence to the classic food pyramid for the required protein quantity and paying attention to the protein index would pave the way for dream realization.

\section{References}

1. Komlos J (2009) How useful is anthropometric history? Munich Discussion Paper No.2009/6, Department of Economics, University of Munich, pp. 1-9. 


\section{Current Research in Diabetes \& Obesity Journal}

2. Samaras TT (2012) How height is related to our health and longevity: A review. Nutr Health 21(4): 247-261.

3. Cole TJ (2000) Secular trends in growth. Proc Nutr Soc 59(2): 317-324

4. Cameron N (2002) Human Growth and Development, Academic Press. An Elsevier Science Company, USA, p. 432.

5. Grasgruber P, Cacek J, Kalina T, Sebera M (2014) The role of nutrition and genetics as key determinants of the positive height trend. Econ Hum Biol 15: 81-100.

6. Singhal A, Fewtrell M, Cole TJ, Lucas A (2003) Low nutrient intake and early growth for later insulin resistance in adolescents born preterm. Lancet 361: 1089-1097.

7. Monteiro PO, Victora CG (2005) Rapid growth in infancy and childhood and obesity in later life. A systematic review. Obes Rev 6(2): 143-154.

8. Prat S, Péan SC, Crépin L, Drucker DG, Puaud SJ, et al. (2011) The oldest anatomically modern humans from far southeast Europe: direct dating, culture and behavior. PLOS One 6(6): e20834.

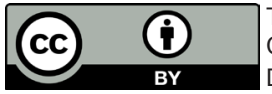

This work is licensed under Creative Commons Attribution 4.0 Licens

DOI: 10.19080/CRDOJ.2017.3.555614
9. Grasgruber P, Sebera M, Hrazdíra E, Cacek J, Kalina T (2016) Major correlates of male height: A study of 105 countries. Econ Hum Biol 21 172-195.

10. https://www.hsph.harvard.edu/nutritionsource/healthy-eatingplate/

11. Otang Mbeng W, Otunola GA, Afolayan AJ (2017) Lifestyle factors and co-morbidities associated with obesity and overweight in Nkonkobe Municipality of the Eastern Cape, South Africa. J Health Popul Nutr 36(1): 22.

12. Jessri M, Wolfinger RD, Lou WY, L'Abbé MR (2017) Identification of dietary patterns associated with obesity in a nationally representative survey of Canadian adults: application of a priori, hybrid, and simplified dietary pattern techniques. Am J Clin Nutr 105(3): 669-684

\begin{tabular}{l} 
Your next submission with Juniper Publishers \\
will reach you the below assets \\
- Quality Editorial service \\
- Swift Peer Review \\
- Reprints availability \\
- E-prints Service \\
- Manuscript Podcast for convenient understanding \\
- Global attainment for your research \\
- Manuscript accessibility in different formats \\
( Pdf, E-pub, Full Text, Audio) \\
- Unceasing customer service \\
Track the below URL for one-step submission \\
https://juniperpublishers.com/online-submission.php \\
\hline
\end{tabular}

